10IKC-69

\title{
GROUNDMASS MICROCRYSTALLINE OXIDES FROM THE MARSFONTEIN PIPE (REPUBLIC OF SOUTH AFRICA), CATOCA, CAMACHIA AND OTHERS ANGOLAN KIMBERLITE PIPES
}

\author{
Garanin VK ${ }^{1}$, Anashkin SM${ }^{1}$, Bovkun AV ${ }^{\mathbf{1}}$, Jelsma H ${ }^{\mathbf{2}}$, Shmakov II ${ }^{\mathbf{3}}$, Garanin KV \\ ${ }^{1}$ M .V. Lomonosov Moscow State University, Moscow, Russia; ${ }^{2}$ De Beers, Johannesburg, Russia; \\ ${ }^{3}$ High River Gold, Ouagadougou, Burkina Faso
}

\section{INTRODUCTION}

Recent studies of microcrystalline $(<100$ $\mu \mathrm{m})$ oxide minerals from the groundmass of Yakutian and Arkhangelsk diamondiferous provinces kimberlites showed that these minerals are sensitive to the origination, evolution and formation conditions of the kimberlitic rocks. Therefore, their compositional peculiarities and mineral ratios could be used potentially as indirect criteria for express-evaluation of kimberlites as potential diamond host (Garanin V.K. et al., 2009).

It was found that indirect criteria for potential diamond-content of kimberlite rocks, reflects the formation depth of kimberlite melts and the possibility of removal of the diamond to the surface, is microcrystalline picrochromites (contain $>40-42$ wt. $\% \mathrm{Cr}_{2} \mathrm{O}_{3}$, and less than 6 wt. \% $\mathrm{TiO}_{2}$ ) and/or microcrystalline chromium picroilmenites ( $>10 \mathrm{wt} . \% \mathrm{MgO}$ and an average 2.3-3.5 wt.\% $\mathrm{Cr}_{2} \mathrm{O}_{3}$ ) presence in groundmass, depending on the specialization of microcrystalline oxides.

Indicators of reducing the original diamond grade, reflecting the length of occurrence the diamond in the transporting kimberlite melt and aggressiveness degree of the latter, are the extensive crystallization trends of microspinellides with successively forming varied composition ulvospinels and titanomagnetites, a large perovskite number $(>30-40 \%$ microoxide phases), etc.

This study's aim was to establish the possibility of using previously identified relationship between microcrystalline oxides and diamond grade for African kimberlites. In this regard, microcrystalline oxides from kimberlitic groundmass were investigated. Kimberlites differ by diamond grade and presented well-known and recently discovered pipes: Marsfontein (South Africa), Camachia, Catoca and other north-eastern

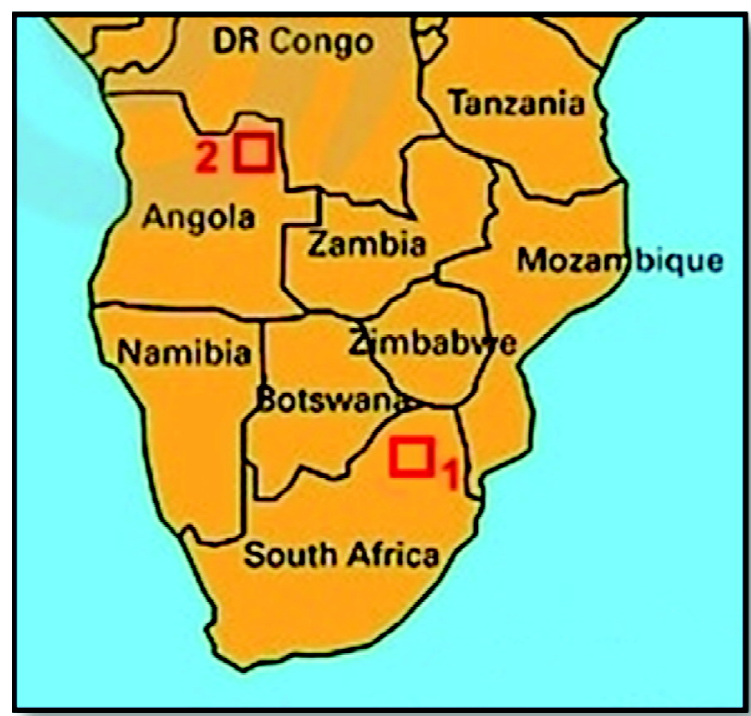

Fig. 1. Schematic location of Marsfontein pipe (1) and Lunda-Norte province pipes (2). 


\section{$1^{\text {th }}$ International Kimberlite Conference, Bangalore - 2012}

Angolan pipes in Lunda-Norte province - X-014, X-037, X-165, X-011, X-060, X-068 and X-004 (Fig. 1).

The Marsfontein kimberlite pipe presents Klipspringer kimberlite swarm (Limpopo province, NE South Africa). The pipe is composed by the highest diamond grade (to $4,5 \mathrm{cts} / \mathrm{t}$ in the superficial deposits capping the pipe and to $3 \mathrm{cts} /$ $\mathrm{t}$ at depth) kimberlite ever mined in southern Africa (McCarthy, Allan, 2007). The kimberlites are of Group II type, and represent hypabyssal facies.

Catoca and Camachia pipes are located in the southern part of Lunda Norte province. The diamond grade in the Camachia pipe is on average about $0.37 \mathrm{cts} / \mathrm{m}^{3}$ (Kharkiv, et al., 1998), in Catoca pipe $0.72 \mathrm{cts} / \mathrm{t}$ (Read, 2008), in the crater part (richest in diamond block) about $2 \mathrm{cts} / \mathrm{t}$ (Ganga et al., 2003). X-014, X-037, X-165, X-011, X-060, X-068 and X-004 pipes are located north-east of the Camachia and Catoca pipes, near the Camafuca-Camazambo pipe. The diamond grade for these pipes is unknown.

\section{RESULTS AND DISCUSSION}

The oxide minerals content in groundmass of the the Marsfontein and Camachia pipes kimberlites is low (2-3 and 1-2 vol.\% respectively). It is higher in the Catoca kimberlites (up to 5 vol.\%). While for others studied pipes of Lunda Norte province it is varying from 1-3 to 57 vol.\%.

Kimberlites of studied pipes differ in groundmass oxide minerals specialization. Crspinellides are prevail among microcrystalline oxide minerals of kimberlite groundmass in the Marsfontein pipe, picroilmenites-Cr-spinellides in the Camachia pipe, Ti-magnetitespicroilmenites in the Catoca pipe. The groundmass oxide minerals specialization is in agreement with the heavy fraction minerals (HFMs) distribution for the Marsfontein and Catoca pipes. So the picroilmenite is substantially absent among HFMs in the Marsfontein pipe kimberlites, while the picroilmenite is widely presented and $\mathrm{Cr}$ spinellides occur sporadically among HFMs in the Catoca pipe kimberlites (Ganga et al., 2003). Data on the HFMs ratio in kimberlite of the Camachia and other pipes of the Lunda-Norte province are not published yet.

The Marsfontein pipe. Porphyritic kimberlites have a higher phlogopite content among groundmass phenocrysts. External sites of zoned mica grains from groundmass composed by tetraferriflogopite (25.4-26.7 wt.\% MgO; 0$1.7 \mathrm{Al}_{2} \mathrm{O}_{3} ; 15.7-18 \mathrm{FeO}_{\text {sum }} ; 0-0.4 \mathrm{TiO}_{2} ; 8.2-9.6$ $\mathrm{K}_{2} \mathrm{O}$ ). Microcrystalline oxide minerals are mainly presented by $\mathrm{Cr}$-spinellide and Ti-magnetite, to a lesser degree by perovskite, and picroilmenite is absent.

The prevalence (about $50 \%$ of all microoxide phases) of picro-chromites with very high chromium, low titanium and iron oxide content (50.8-61.5 wt. \% $\mathrm{Cr}_{2} \mathrm{O}_{3} ; 10-15 \mathrm{MgO} ; 1.2-$ $4.3 \mathrm{TiO}_{2} ; 2.8-12.7 \mathrm{Al}_{2} \mathrm{O}_{3} ; 2.8-10.7 \mathrm{Fe}_{2} \mathrm{O}_{3}$ ) is a characteristic feature of the Marsfontein kimberlites. It indicates the origin of the kimberlite pipe forming melts at great depths in the thermodynamic diamond zone stability and it is also an indirect indicator of very high potential diamonds grade. Such Cr-spinellides are typomorphic for high-diamondiferous Aikhal, Nurbinskaya, Botuobinskaya (Yakutian diamondiferous province) and diamondiferous M.V. Lomonosov deposit (Archangelsk diamondiferous province) kimberlites, which are mining in Russia.

In addition, microcrystalline kimberlitic $\mathrm{Cr}-$ spinellides of the Marsfontein pipe have a pronounced incomplete crystallization trend: from high-chromium picrochromite to magnesian $\mathrm{Ti}$ magnetite without a phase of intermediate composition (Fig. 2) and relatively good Crspinellide safety as not all picrochromite grains are surrounded by Ti-magnetite rims (Fig. 3). These signs indicate a high rate of rise of the kimberlite melt to the Earth surface in conditions 


\section{0 $^{\text {th }}$ International Kimberlite Conference, Bangalore - 2012}



Fig. 2. diagram for groundmass microcrystalline spinellides Composition from kimberlites of the: Camachia (1), other Lunda Norte province (2), and the Marsfontein (3) pipes

of uneven PT-parameters changing and mineralforming redox environment, as well it is an indirect indicator of the favorable conditions for the diamond preservation in the during the pipe formation.

There is only an increased amount of perovskite (up to $20 \%$ of all mikrooksidnyh phases) is detected among the factors affecting the diamond preservation in the Marsfontein pipe kimberlites.

The Camachia pipe. Ferrispinellides $(\mathrm{Cr}-$ containing $\mathrm{Mg}$-ulvospinels and $\mathrm{Mg}$-Timagnetites) are dominated (up to $40 \%$ of all oxide phases) among the microcrystalline oxide minerals from kimberlitic groundmass of the Camachia pipe. The picroilmenite is also enough
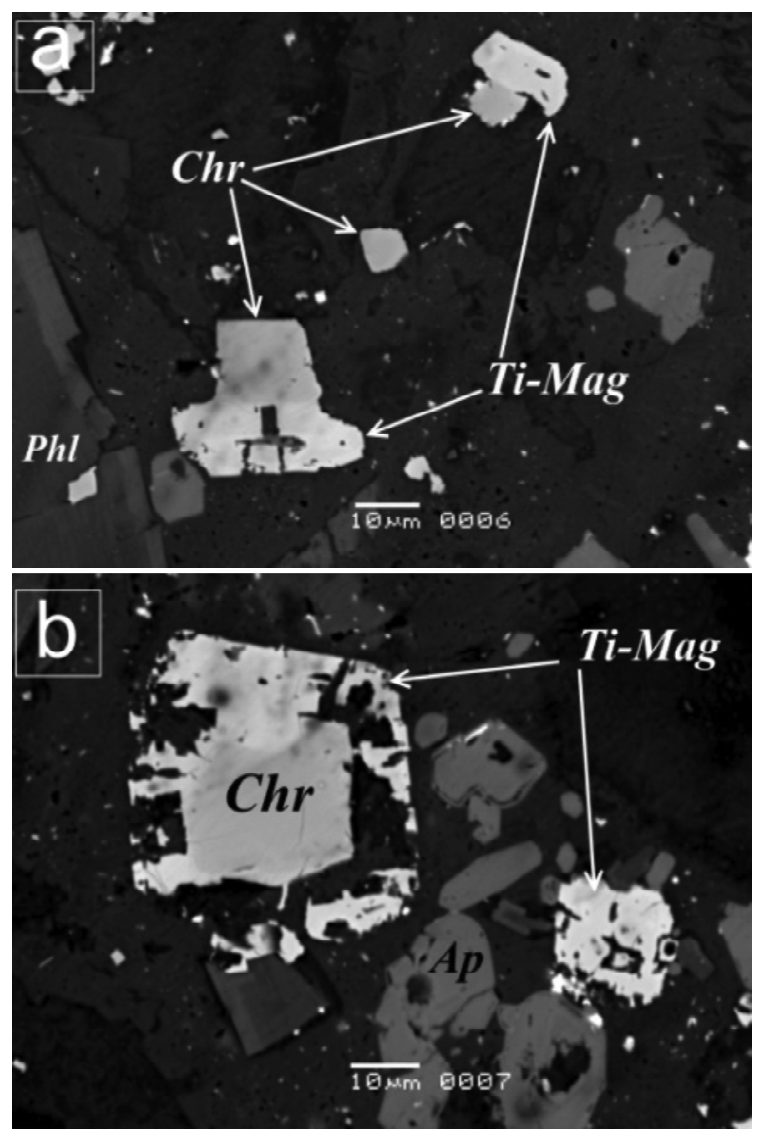

Fig. 3. Picrochromite (Chr) and Ti-magnetite (Ti-Mag) in the groundmass of the porphyritic kimberlite from the Marsfontein pipe. SEM image in BSE format.

widely presented and rarely $\mathrm{Cr}$-spinellides and rutile.

The picrochromite presence (42-43 wt. $\%$ $\mathrm{Cr}_{2} \mathrm{O}_{3}, 6.8-7.2 \mathrm{TiO}_{2}$ ) and the prevalence of microcrystalline $\mathrm{Cr}$-containing picroilmenite (up to $14 \mathrm{wt} . \% \mathrm{MgO}, 1.3 \mathrm{Cr}_{2} \mathrm{O}_{3}$ ) are indirect criteria potential diamond grade for Camachia pipe kimberlites, but the rarity of such Cr-spinellides and the relatively low $\mathrm{Cr}$-content in microcrystalline picroilmenite indicate a moderate potential diamond grade of the kimberlites, markedly lower than for the Marsfontein pipe kimberlites. In addition, there were conditions unfavorable to the diamond preservation in the process of th Camachia pipe kimberlites formation. This is indicated by an extended trend 


\section{0 $^{\text {th }}$ International Kimberlite Conference, Bangalore - 2012}

of microcrystalline spinellides crystallization (Fig. 2), the abundance of high-titanium phases (ulvospinels with high Ti-content - up to 22 wt.\% $\mathrm{TiO}_{2}$ and Ti-magnetite), poor Cr-spinellides preservation (always surrounded by Ti-magnetite rims), and a high resorption and substituted degree of picroilmenite by polymineral rims (Fig. 4). The totality of these facts points to the relatively slow kimberlite melt rise in conditions of a gradually increasing oxidizing potential, high titanium activity and high mineral-forming environment alkalinity, which undoubtedly caused the potential diamond grade reduction of these kimberlites.
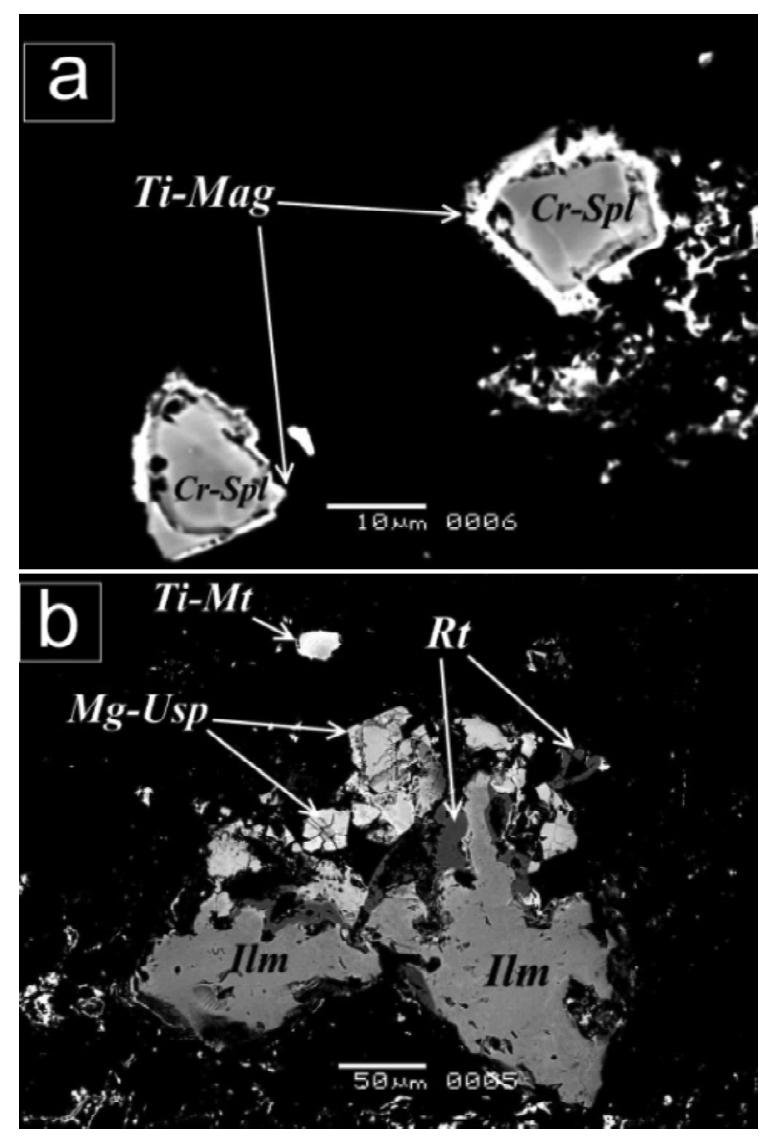

Fig. 4. Zonal allocation with $\mathrm{Cr}$-spinellide cores and Ti-magnetite rims (a) and altered ilmenite relics (b) in the groundmass of the Camachia pipe kimberlitic breccia. SEM image in BSE format. Cr$\mathrm{Spl}$ - Cr-spinellides, Ti-Mag - Ti-magnetite, Ilm - Mg-ilmenite, MgUsp - Mg-ulvospinel, Rt - rutile
Catoca pipe. Groundmass microcrystalline oxide minerals in the porphyritic kimberlites of the Catoca pipe are represented by numerous ilmenite allocations, to a lesser degree by $\mathrm{Ti}$ magnetite and magnetite, $\mathrm{Cr}$-spinellides are absent. There is a large number of Mg-ilmenite xenocrysts $(>100 \mathrm{~mm}$ ) with wide compositions range, some of them correspond to deep diamond paragenesis picroilmenite. High magnesium and chromium contents with a small ferric iron amount (up to 17.5-19.3 wt.\% $\mathrm{MgO}, 1.2-6 \mathrm{Cr}_{2} \mathrm{O}_{3}$; 0-5.4 $\left.\mathrm{Fe}_{2} \mathrm{O}_{3}\right)$ is a characteristic feature of microcrystalline $\mathrm{Mg}$-ilmenite from the Catoca pipe. It indicates the kimberlite melt was originated at sufficiently large depths (in the "diamond zone" of the lithosphere mantle) and it is also an indirect potential diamond grade indicator of the Catoca pipe kimberlites.

The number of Mn-rich magnesium and iron ilmenite (up to $7.2 \mathrm{wt} \% \mathrm{MnO}$ in individual grains and up to 19 wt.\% $\mathrm{MnO}$ in the rims around picroilmenite) is distinctly increased in groundmass of porphyritic kimberlites in deep horizons (360-400 m). The edges of almost all Mg-ilmenite xenocrysts and most of microcrystalline $\mathrm{Mg}$-ilmenite are resorbed in varying degree and replaced by magnetite (Fig. 5) or Mn-ilmenite (at deep levels). It is indicating a high oxidation potential and an increased Mnactivity in mineral environment at the final stages of the pipe formation. This, in turn, suggests the possibility of widespread corrosion exertion on the diamond crystals surface. That conclusion confirmed by J. Ganga et al. (2003) results - about $74 \%$ of the Catoca pipe diamonds are corroded. Within the Yakutian diamond province kimberlites with picroilmenite-Ti-magnetite microcrystalline oxides specialization, where $\mathrm{Cr}$-spinellides are absent in the heavy fraction and groundmass, are relatively rare and are usually characterized by low diamond grade (Komsomolskaya, Leningradskaya and Morkoka pipes, AN-21dike). It should be noted - there are common perovskite and/or rutile grains in the kimberlite groundmass 

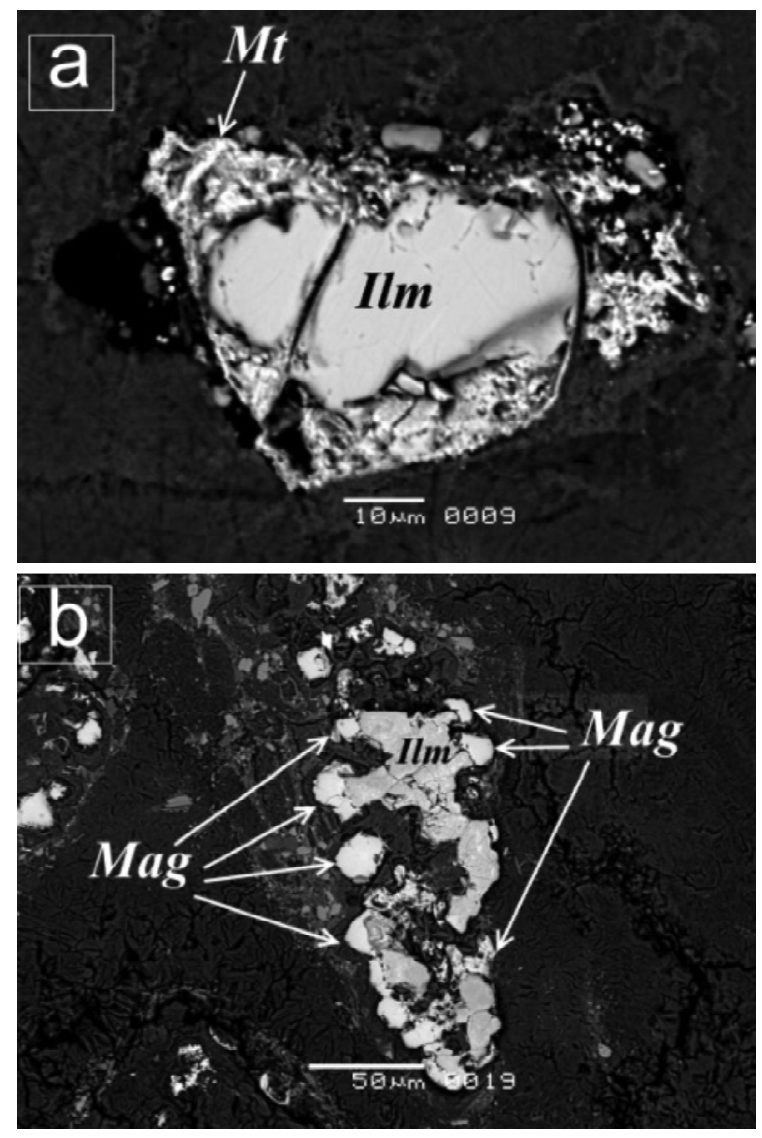

Fig. 5. Resorbed grains of microcrystalline (a) and xenogenic (b) Mg-ilmenites (Ilm) with magnetite (Mag) rims in the groundmass of the porphyric kimberlite from the Catoca pipe. SEM image in BSE format.

of these pipe in contrast to the Catoca pipe kimberlite.

The others Lunda Norte province pipes. the X-014, X-037, X-165, X-011, X-060 and X068 pipes' kimberlites are most similar to the Catoca pipe kimberlites according to groundmass oxide mineralization kimberlites, because they have picroilmenite-Ti-magnetite groundmass oxide specialization and do not content of microcrystalline $\mathrm{Cr}$-spinellides. Rare fine $\mathrm{Cr}$ spinellides relics with a maximal chromium content 22.5-23.9 wt. $\% \mathrm{Cr}_{2} \mathrm{O}_{3}$ (with 12-12.4 wt.\% $\mathrm{TiO}_{2}$ ) were found only in nuclear parts of the complex zonal allocations in the groundmass of the X004 pipe kimberlites. It is not excluded that more chromium spinellides were in the kimberlites of the X004, but they have been completely replaced by later phases.

As an indirect indicator of the potential kimberlites diamond-grade of the mentioned above Lunda Norte province pipes can be a microcrystalline chromium picroilmenite presence. At this rate the microcrystalline picroilmenite composition (11.9-16.6 wt.\% $\mathrm{MgO}$, 2.1-7,9 $\mathrm{Cr}_{2} \mathrm{O}_{3}$, up to $5 \mathrm{MnO}, 8.5-12.6 \mathrm{Fe}_{2} \mathrm{O}_{3}$ ) of the $\mathrm{X}-014$ kimberlite indicates the kimberlite melt crystallization was at high PT-parameters close to the conditions of Mg-ilmenite genesis in mantle rocks. The composition of the microcrystalline Mg-ilmenite (generally 11-15 wt.\% MgO, 0-6 $\mathrm{Cr}_{2} \mathrm{O}_{3}$; up to $4.3 \mathrm{MnO}, 14-25.7 \mathrm{Fe}_{2} \mathrm{O}_{3}$ ) from kimberlites the others Lunda Norte province kimberlites suggests its diamondiferous potential, but probably lower, than for X-014 kimberlites.

It should be noted that the microcrystalline $\mathrm{Mg}$-ilmenite from these pipes is different from the Catoca pipe picroilmenite by higher ferric iron content, indicating its formation in more oxidizing conditions.

All of Lunda Norte province pipes were formed in conditions of high titanium activity and high oxidation potential, which in total is very unfavorable for the diamond preservation. The abundance of Ti-magnetite and magnetite phases (Fig. 6a), the higher iron content (including ferric) in sphene is also an evidence of a high oxidation potential in the kimberlites crystallization process.

The sphene abundance (to a lesser degree of perovskite) and high Ti-content (8.5-24.8 wt.\% $\mathrm{TiO}_{2}$ ) in the majority of Ti-magnetites (up to the $\mathrm{Mg}$-ulvospinel formation), in turn, indicate the kimberlite melt enrichment by titanium (Fig. 6). Similar composition ferrispinellides observed in the Camachia pipe kimberlitic groundmass.

Perhaps the higher sphene content in the groundmass of Lunda Norte province kimberlites is an additional factor negatively affecting on the diamond preservation. A massive perovskitization 


\section{$1^{\text {th }}$ International Kimberlite Conference, Bangalore - 2012}
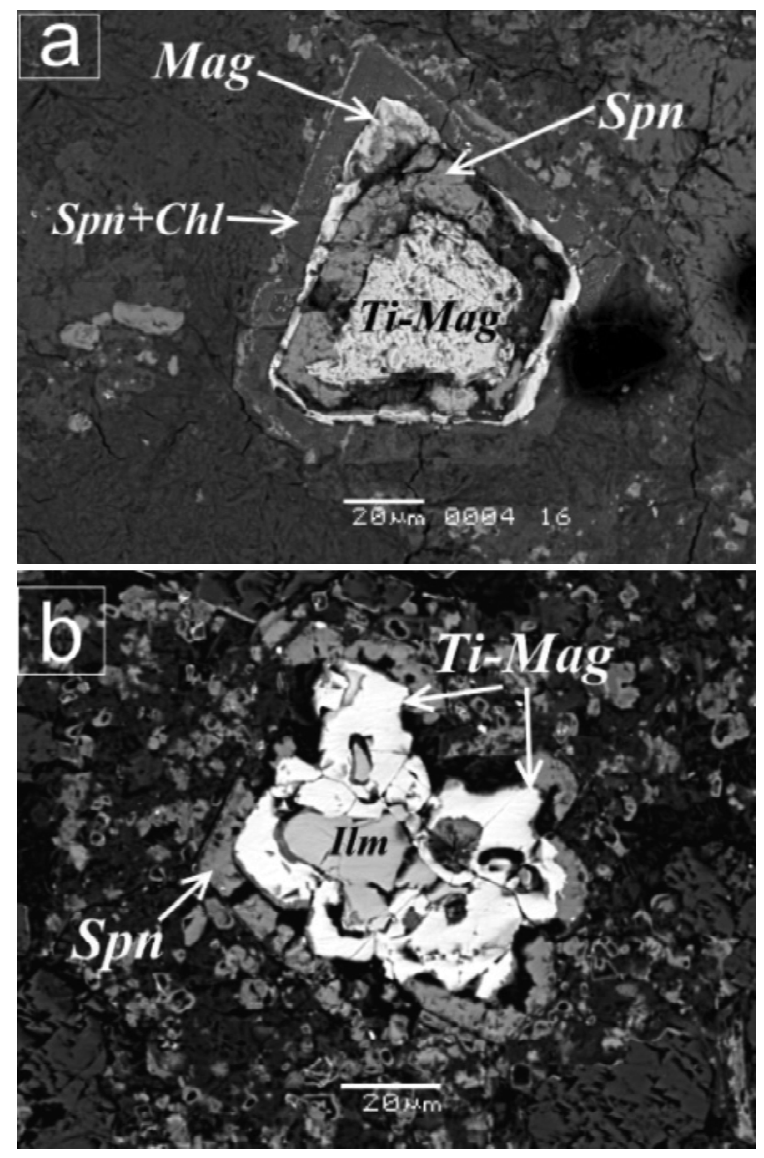

Fig. 6. Zonal formation with Ti-magnetite core (à) and Mg-ilmenite (b) core and complex rims in the kimberlitic groundmass of the Õ037 (à) and Õ-165 (b) pipes. SEM image in BSE format. Ti-Mag Ti-magnetite, Ilm - Mg-ilmenite, Spn - sphene, Spn+Chl serpentine+chlorite, Mag - magnetite

of picroilmenite is identified for the $\mathrm{X}-014$ pipe kimberlites body, where sphene is uncommon.

Mg-ilmenite allocations in kimberlites of other Lunda Norte province pipes are usually resorbed and almost always surrounded by Timagnetite and sphene reaction rims (Fig. 6b), sometimes with magnetite and perovskite prence, which once again underlines the formation of these bodies in unfavorable conditions to the diamond preservation. Thus, it is possible to conclude that the initial relatively low diamondiferous potential of studied Lunda Norte province kimberlites, probably, was markedly reduced during the kimberlite melts recovery to the surface.

\section{CONCLUSION}

Results analysis suggests that features of the proportion, chemical and phase compositions of microcrystalline oxides from African kimberlites groundmass correlate with a varying diamond grade of these rocks. Thus, the previously developed indirect express-estimation criteria for a diamondiferous potential determination of Yakutian and Archangelsk diamond province kimberlites can be successfully applied to other kimberlite provinces of the World.

\section{References}

Garanin V.K., Bovkun A.V., Garanin K.V. et al. (2009) Microcrystalline oxides from Russian kimberlites end related rocks. Moscow: GEOS Press, 498 p.

McCarthy T.S. and Allan J.G. (2007) A possible new alluvial diamond field related to the Klipspringer kimberlite swarm, South Africa. South African Jour. of Geology, v. 110, pp. 503-510.

Ganga J., Rotman A.Y., Nosiko S. (2003) Pipe Catoca, an example of the weakly eroded kimberlites from North-East of Angola. The 8th Int. Kimb. Conf., Extended Abstract No. FLA_0312.

Read G.H. (2008) Diamonds: exploration, mining and marketing. The 9th Int. Kimb. Conf., Extended Abstract No. 9IKC-A-00331.

Kharkiv A.D., Zinchuk N.N., Kryuchkov A.I. (1998) Diamond primary deposits of the World. Moscow: Nedra Press, 555 p. 